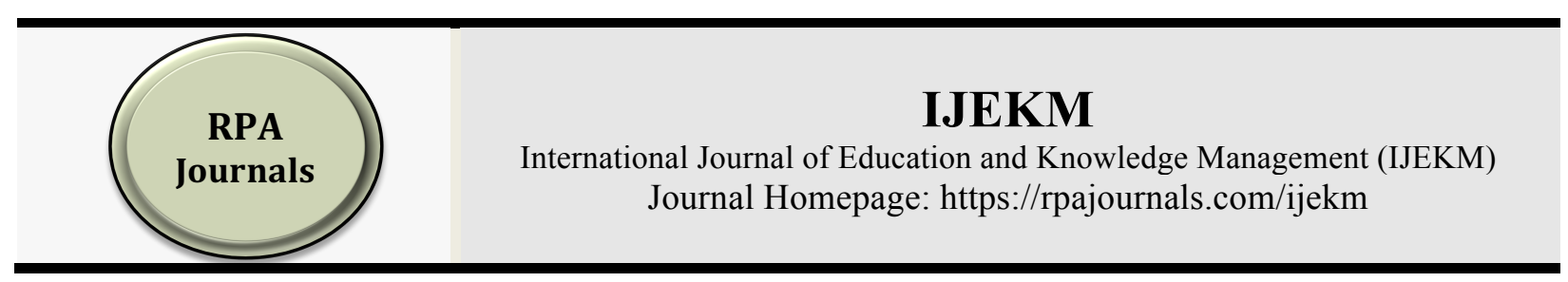

\title{
Religion and Culture in Algeria: The Impact of Religious Interpretations on Social Practices
}

\author{
Salim Bouherar \\ Department of Foreign Language \\ Mohamed Al Bachir El Ibrahimi University, Algeria
}

\begin{abstract}
It is almost impossible to separate culture and religion in Algeria because of the huge overlap between the two. Despite the globalised world we live in now, most of the Algerian societies are still conservative. In this paper, I shed light on the relationship between religion and culture in Algeria and unveil the nature of this reciprocal relationship by digging into the religious jurisprudence and social practices of Algerians. This paper discusses the religious practices in Algeria and their effect on the Algerian social practices including cultural practices. It explores the various religious jurisprudence and clarifies their ideologies. This paper also stresses that the tenets and beliefs of religion are one but the interpretation of individuals varies accordingly. The article also shows that a large proportion of Algerian culture is derived from Islamic beliefs and therefore the practices echo people's religious belongings. This paper aims to show that religion is the main source that can explain most of the people's social and cultural practices.

Keywords: Religion, Islam, Jurisprudence, Interpretations, Cultural Practices.
\end{abstract}

*Corresponding author: Salim Bouherar; Email: salim.bouherar@gmail.com DOI: https://doi.org/10.37227/ijekm-2020-09/

\section{Introduction}

As this paper aims to investigate the outcomes of religious practices and beliefs on shaping presiding cultural assumptions in Algeria, it is significant to take the first step to define religion. Religion, as defined by Grus (2009) is a set of beliefs and practices that involve cultural traditions that guide human life and define human nature. For other authors (such as: Dawes \& Maclaurin, 2013, Bergunder, 2014, Harrison, 2006 and others), the term 'religion' is itself complicated to be defined. Therefore, we find Nye (2008) who links religion with other social and cultural activities:

"For many, there is a clear idea that religion is something that involves going to church (or some other religious centre), reading and reflecting on certain sacred texts, believing and having faith, performing certain ritual practices, and (/or) living one's life in a certain way. It is the case that religion often involves some or all of these things, but we also need to recognise that it can (and often does) involve a lot more. When we look at religion cross-culturally - in different contexts and societies across the globe - religion very often impacts on all levels of life, at both the individual and social level (Nye, 2008: 2)." 
We have to admit that it is always difficult to set fixed definitions of how people accept certain religious faiths and ideologies and defend them through their daily practices. Those daily practices create cultural practices as well that are derived from religious beliefs. Culture, in this case, fits adjustably into religious dogmas. However, is this relationship reciprocal?

The answer is probably yes but to what extent does culture affect religion? It is a question that might need further investigation. According to Nye (2008), the research on religion and culture are inextricable. Beyers (2017), asserts that people who are part of one culture are also part of a certain religion in the sense that culture implies necessarily the embrace of certain religious values. This means that different cultures infer different religions or at least religious ideologies under the same set of one religious belief. In the case of Algeria, various cultural practices may necessarily entail certain dogmatic religiosity that is familiar to the society members that share the same practice. However, there are different types of cultures according to Williams (1998): the ideal, the documentary, and the social one. The type of culture that I discuss in this article with reference to religious practices is the social culture. By social culture, Williams (1998) means culture that describes aspects and values of life as embodied in institutions and behaviours of individuals.

The aim of this article is to explore these cultural practices and their relation to religion as an Islamic philosophy that guides and legalises peoples' understanding of worship, god, spirituals, and social practices. The structure of this paper is as follows: section 2 is an overview of the current cultural and social status in Algeria. Section 3 discusses the objectives and the research questions of the paper. Section 4 displays the methodology. Section 5 discusses the prevalent religious groups in Algeria in general. Section 6 presents details about each dominant religious group and finally, Section 7 reflects on the cultural practices in each religious group claiming that religious interpretations and practices have a strong influence on shaping most of the cultural assumptions in Algeria.

\section{An Overview of the Algerian Society and the Religious Doctrines}

An overview of Algeria's social and religious status is necessary to set the scene of discussion about the effects of religion in Algeria on the social and cultural practices of people. Algeria witnessed many invasions throughout history among which Romans, Turks, and French colonisations were the most influential over the current cultural heritage Algeria has nowadays (the use of 'colonization' is debatable over the Islamic and the Turkish expansions). Mensour (2010) claims that Ibn Khaldun stated that North Africa (including Algeria) was ruled by a tribalism system united together against wars and invasions. This social status described in tribal governing continued during the beginning of the French colonisation to the country as well (Mensour, 2010). However, the tribal social system was divided and weakened by the French colonisation to gain control over society (Benaissa, 2010). Nowadays, this social system exists only in certain regions in Algeria but not in metropolitan cities where life there takes more of an individual pattern.

Among the consequences of the French colonization to Algeria is regionalism that is, now, widely spread in the society. Hadji (2018) claims that after independence, Algeria continued to support certain partially developed regions that received the same privileges during the French colonization. That is, France aimed to regionalise the country to gain

International Journal of Education and Knowledge Management (IJEKM) 
easy control over the land but this policy continued to exist throughout the Algerian economic and political strategies that governed the country since 1962.

The reflections of Algerian history (and the current political management) on the society have clear manifestations as mentioned previously. It cracks the Algerian society and widens the gap between its citizens. For instance, inhabitants of the south (Sahara) might have certain stereotyping thoughts about inhabitants of the north because of 'better' social status that is attributed to the north of Algeria.

Another colonial heritage is the vernacular language that Algerians speak daily. The Arabic language spread in Algeria was due to the Islamic expansions when Berbers accepted/converted to the Islamic religion (Khaladi, 2015). As also there is the French language that is used regularly in Algeria which is a heritage of the French who lived in Algeria. Besides these languages, there is the Tamazight language with its different dialects that are spoken in various regions. The Tamazight language might not be a colonial heritage but the indigenous language of North African although further investigation is needed to explore this view fully in detail as it is a controversial debate in Algeria.

Furthermore, there exists a linguistic identity crisis in Algeria because of the clashing thoughts of many writers about which language is colonial and imperialist? Arabic, French, or Tamazight? Daoud (2013) (who is a writer and free thinker in Algeria) claims that the Arabic language carries some colonial ideologies hidden under the cover of religion. He (2013) considers it a colonial language that is forced on the society and accepted by Algerians. Perhaps, the majority of Algerians would consider the French language colonial as well. Discussing the current linguistic situation in Algeria would take the time and effort to write another article on this but this is just to shed light on the general current linguistic trends as an overview of Algerian societies before addressing religious issues.

The multilingualism in Algeria created cultural classes in society and widened the gap between people's linguistic choices (Sahraoui, 2009). Despite the political and linguistic issues Algeria has, the far majority of Algerians are Muslims. Kettani (2010) claims that more than $99 \%$ of the Algerian population are Muslims. However, there exist also different orientation groups under the monotheism belief.

Koenig and Al Shohaib (2014) claim that Islam has two main orientations that are Sunni and Shia and there are also other ideologies such as Sufism which may rank low in terms of its followers. They (2014) assert that Sunni is the dominant religious sect with more than $80 \%$ of Muslims embracing it, Shia, they claim, has fewer followers that rank second with less than $15 \%$ and Sufism is less than $5 \%$. These are the main dogmatic understanding of Islam but there are many other sub-sects under each religious orientation. The Sunni sect, for instance, has four major religious branches: Maliki, Hanafi, Hanbali, and Shafi'i. The Shia sect has also many religious denominations such as the Twelvers, Alvis, Ismailism, Druze (also known as a minority in the Middle East and Asia), Zaidi and others. The same could be said about Sufism.

Mentioning these different religious sects is necessary to discuss the various cultural assumptions that are informed by the religious sects. It is also significantly important to clarify the dominant religious understandings so that we can explain the origins of different cultural practices as the aim of this paper is to show how much the understanding of religion can create certain well-established cultural practices.

International Journal of Education and Knowledge Management (IJEKM) 
Algeria's Islamic religious sect is dominantly Sunni (Boyle \& Sheen, 1997). There are also other religious denominations in Algeria such as Sufism (Entelis, 2016) and Shia (Sawe, 2017). There are some clashing thoughts, however, between the religious and social practice of Sunni sect in Algeria and the government's religious tendencies that are slightly oriented towards Sufism. Azazga (2018) asserts that the Minister of Religious Affairs in Algeria stated that Algeria is Sufist and has a Sufism religious orientation. Although it is fairly known that the Islamic mainstream views are Maliki but the religious governmental institutions claim Sufism. These 'opposing' thoughts have led to different religious classes in society that this article discusses in the coming sections with further resulting cultural assumptions.

\section{Objectives and Research Questions}

The objective of this article is to critically argue that the main source of cultural practices in Algeria originate from religion and religious sects and practices. Although Herbi (2010) links religion in Algeria to a more political movement, I discuss religion in isolation of politics in this paper and claim that religion is the focal point of culture in Algeria through which different inherited religious practices dictate specific cultural beliefs and unite communities. The research questions that this paper investigates are as follows:

1. How does religion shape the cultural beliefs and practices in Algeria?

1.1. Are the social practices informed by how societies in Algeria practice religion?

2. What are the main religious sects in Algeria?

3. Considering the reciprocal relationship between religion and culture, which one is more influencing and dominant in Algerian societies?

\section{Methodology}

In terms of the research method followed to obtain and analyse data, it is a conceptual analytic method (Furner, 2004). This methodology describes a theory-based research in the sense that it analyses the concept of religion as used in Algerian societies and investigates the outcomes on the cultural traits shared by many groups and communities. According to Rodriguez-Blanco (2005), conceptual analysis is a group of features that target a philosophical notion to clarify thoughts and ideas. He (2005) adds that the goal of the conceptual analysis method is to describe concepts with reference to other concepts. In the case of this research, I analyse the concept of religion with reference to cultural practices and argue that religious sects contribute to shape major cultural traits in Algeria.

The data I base my arguments on are secondary data that discuss multiple religious practices in Algeria. Johnston (2014) avows that secondary data uses the same research principle used in primary data as it is an important method to use in the process of inquiry if a systematic method is followed. The issue with the use of secondary data in this research is that there are not enough data that discuss concepts of religion and culture in Algeria (except some publications that talk about the history of Algerian cultures since early 1500 to 1962 such as 'The cultural history of Algeria' authored by Abou-Alkacem Saad Allah (1998) of 10 volumes). 


\section{Islam and Inferences in Algeria}

In this section, I discuss the different understandings of Islam in Algeria and emphasise that religion as a sacred entity can only bear to one and unique explanation but people's understandings and practices differ considerably. These understandings generate many cultural beliefs and practices that are mainly explained in Section 7.

The transcendent of religion, in this instance, Islam, is something to believe and not to dare in most cases of worship. In a more comprehensive analogy, I would say that linguistic theory considers an ideal listener and speaker of the language according to Chomsky's view of language use (Derwing, 1973). Language here is considered to be an ideal system and a combination of codes that loses its perfection when used/spoken by individuals. Religion, namely Islam, is one in terms of laws, beliefs, and revelation but the various understandings of these religious legislations differ from one group to another which contribute massively in forming thorough cultural assumptions.

I focus my discussion on three main subjects that manifest different understandings of religious legislation in Algeria which pave the road to discuss the various religious groups and their cultural practices in Sections 6 and 7. It is important to clarify the degree of interpretation differences as Islam acknowledges different opinions of scholars. According to the hadith of the prophet Mohammed (peace and blessing be upon him) saying that:

"If a judge gives a verdict according to the best of his knowledge and his verdict is correct (i.e. agrees with Allah and His Messenger's verdict), he will receive a double reward, and if he gives a verdict according to the best of his knowledge and his verdict is wrong (i.e., against that of Allah and His Messenger) even then he will get a reward, (Khan, 1997: 271)."

This hadith infers that differences in interpretation are considered in Islam to a certain degree. However, the variability I show in Section 6 might entail a fairly different comprehension of the scripts.

This variation in interpretation defends different religious ideologies with different dimensions and purposes in Algerian societies. This leads, accordingly, to clashes and discrimination between these different religious spectra in society.

It is important to clarify that different interpretations of religious scripts do not mean that there is a dynamic change in explaining religion and religiosity. It is, instead, the understanding of humans to the best of their knowledge (often) and the best of their advantage/interest (sometimes) that is dynamic. This leads me to discuss the various religious groups in Algeria and the ideological religious clashes that feed this variability of religiosity though that this article's interest is not to show the religious clashes but rather to emphasise on the resulting cultural practices.

\section{Islamic Sects in Algeria}

A religious categorisation of the current groups (or sects) needs to be established in this section to link it with the cultural practices. A platform of the different religious sects and belongings is necessary in this section. There are different religious groups in Algeria. Due to the lack of resources on this topic, I focus my discussion on four major branches which are: Sunnis, Sufis, Shia, and Ibadi. It is worthy of mentioning that each religious group that 
holds slightly different ideas compared to other groups is potentially a religious ideology with potential cultural beliefs and practices. This can be seen in the practices that each group performs in society (more details on this can be found in Section 7).

\section{The Sunni Maliki Doctrine}

To start with, the Sunni Maliki doctrine is the dominant group in Algeria. This doctrine is referenced back to Al-Imam Malik Ibn Anes, one of the followers of the Prophet (peace and blessing be upon him). He was born in Yemen and raised in Medina (Saudi Arabia) where he studied Islamic sciences and published many books, among which 'Al-Muwataa' his famous book (Al-Zerikhi 2017).

The followers of this branch have created different Maliki versions accordingly to their ideologies. There is, for instance, the Maliki Sufi that the Ministry of Religious Affairs adopt in its religious institutions such as Zawaya (this is similar to mosques but used to teach Quran to children mostly) as claimed previously. This is a form of hybridity between two slightly different doctrines. The religious reference as called by many religious figures and even the Minister of Religious Affairs in Algeria, who stresses this in his interventions, is believed to be Maliki reference and not any other Sunni branch (i.e. Hanafi, Hanbali, or Shafi'i). The same Minster declares that Algeria is Sufi (Azazga 2018) in terms of religious beliefs and practices. The religious reference here may infer a new Maliki hybridity with the integration of Sufi ideas and practices in some mosques and Zawaya. The bottom line is that religious reference is ambiguous and may need further clarification on its regulations and structure. There could be two main explanations for this: either there is a misunderstanding or interpretation of the Maliki doctrine adopted by the Algerian government (i.e. religious affairs) or there is an intended religious movement that covers the Sufism practices under Maliki religious reference.

There is also another Maliki branch that is concerned with Muslim Brotherhoods' ideas in Algeria. This religious movement has strongly influenced the political Algerian scenes since the late 70s until nowadays (more details of the social and political practices of this group are discussed in section 7). Interestingly, there is a vigorous dispute between this group and the Salafist group (which is also another Sunni group but holds different religious interpretations).

The Salafists are also considered a Sunni Maliki group in Algeria. Ben Massoud (2018) claims that the Salafist movement in Algeria is inspired by Saudi Arabia's religious orientation led by Sheik Rabee Al-Madkhali ideas and fatwas in many issues such as protests, elections, strikes ... etc. Moreover, the Salafists claim that the true Sunna is the one that righteous predecessors used to follow and this excludes many groups among which Muslim Brotherhoods are concerned (Ben Massoud 2018). The Muslim Brotherhoods also accuse the Salafists of being reductionist on declaring themselves as the only group that follows the Sunna of the Prophet (peace and blessing be upon him). However, both groups are considered by Sufism (especially the government religious legislative power) are foreign religious doctrines that oppose the implementation of the socalled 'the religious reference' in Algeria. Zakhrir stated that the Algerian youth is attracted to different religious doctrines because they travel to countries that practice these religious ideologies such as Yemen and Saudi Arabia and they ignore the importance of 'the religious reference' in Algeria (Dhib 2017).

As a result, there is a disparity between all the Sunnis groups as discussed above with regards to the understanding and religious references each group follows. This affects

International Journal of Education and Knowledge Management (IJEKM) 
the social and cultural practices of Algerians at many levels as this religiosity of society can explain many cultural phenomena. The richness of this religious group can be studied at different levels that this article details the cultural traits resulting from these ideoreligious clashes.

\section{The Sofi Doctrine}

The second dominant religious group after Sunni Maliki is Sufism in Algeria. As the Minister of Religious Affairs in Algeria claimed that Algeria follows the fundamental Sufi sect, this manifests clearly into the surface in some of the Algerian religious institutions such as Zawaya. The beginning of Sufism was due to the socioeconomic conditions of Muslims in the early Islamic state (which manifested a good progress at all levels) where primeval pious Muslims to turn to the mystical status and leave the defective world (Knysh 2017). This is to isolate the human body from all desires and pleasures that may lead to temptation and deviation and to dedicate one's life to worship only.

There is a clear tension between the followers of this sect and the Sunnis in Algeria. A tension that involves debates and dispute on media channels and some seminars and conferences that addresses the religious reference of the country. Interestingly, there are also many different types of Sufism in Algeria (Al-Khadiriya, Al-Rahmaniya, AlShadhiliya, Al-Tijaniya, (Boughdiri 2015). Some of these types are originally from the Middle East and others are from Morocco (Boughdiri 2015). As a recap to the claim of Zakhrir that there are foreign religious sects among Algerian youth that oppose the religious reference in Algeria (Dhib 2017), Sufism is also considered foreign religious doctrine if we look at its origins.

Despite this obscurity, the increasing number of Sufi's branches and sub-sects has a great influence on the Algerian cultures and social practices (details of these practices are discussed in Section 7).

\section{The Shia Doctrine}

The Shia sect followers in Algeria are very few. Ben-Khalifa (2018) claims that Anouar Malek (who is an Algerian journalist) stated that Shia followers in Algeria are around 7000 individuals which is less than $0.02 \%$ of the whole population. However, there are no accurate statistics about Shia in Algeria because their religious practices are not open to the public.

The origins of Shia according to Atbi (2015) are traced back to Abdullah Al-Shi'i and his preaching in North Africa. According to Waqas (2016), the Shia movement started with a protest against the election of the Caliphate claiming that Ali should be the first Caliphate instead of Abu Bakr. Like any other religious sect in Algeria, Shia's followers also disagree with other followers of other religious branches about many things and they claim different interpretations of Hadith and Quran as well.

It is not clear how might the Shia sect's religious practices be part of the Algerian cultures because the vast majority of the Algerian population is Sunni. Second, the religious practices of Shia may not affect the Algerian culture and daily life practices because their rituals come in complete denial to the ones that are recognised in the Algerian societies, may be completely new to most Algerians.

\section{The Ibadism}

Daoudi (2012) claims that Ibadism is traced back in history to Abdullah Ibn Ibad. It appeared as an independent sect in the first century Hijri (Al-Barouni 1995). The followers 
of this sect are claimed to be among the Kharijites (or also known as Khawarij), however, they refuse to be attributed to this group (Daoudi 2012). Ibadism as a religious sect is spread in Oman and parts of Algeria, Al-Barouni (1995), known as Ghardaya province.

The Ibadis, similarly to some other sects, they have different sub-sects or branches that are under the main umbrella of Ibadism. There are seven groups of Ibadis: AlSakhakiya, Al-Fertiya, Al-Hoceiniya, Al-Khaliya, Al-Nafatiya, Al-Nakhariya, and AlIbadiya Al-Wahbiya (Daoudi 2012).

Hamadou (2009) asserts that the Ministry of Religious Affairs in Algeria does not claim that there is a religious clash between Ibadis and Maliki in Algeria as declaring differences blatantly may lead to instability in the country.

At the end of this section, I would like to quote a hadith that predicts the fact that there will be different sects in Islam. The Messenger of Allah (peace and blessing be upon him) said that:

“... this Ummah will split into seventy-three sects, seventy-two of which will be in the fire, and one in the paradise. That is the Jama'ah (main group of Muslims), Al-Khattab (2008: 155).”

However, almost all religious groups declare themselves as the only religious group that the Prophet (peace and blessing be upon him) meant in his hadith.

This manifests that religion is deeply rooted in many Algerian societies with different practices that are now culturally based by definition. In the next section, I display the overlap between religion and cultural practices in Algeria and focus on the religious groups I discussed in this section to show their social extensions and belongings.

\section{Social and Cultural Practices with Reference to Existing Religious Jurisprudence}

In this section, I discuss the various cultural practices that originate from the religious sects I explained previously arguing that religion is the first and most inspiration to culture in Algeria. Although these practices are sourced from religion, they are now considered as social or more of cultural practices in societies. This is to show that the main cultural and social legislation in Algerian societies is religion along with history and other elements that shape the Algerian cultures.

It is interesting to see how religion can create certain cultural assumptions in societies. The purpose of this section is to show that Algerians, with their different religious groups, adhere to the same scripts of the Quran and hadith to make judgments or act on the basis of which these can govern their social interactions. Every group creates its comfort zone of religious practices and defends its values of belonging to the group. Between the clashing thoughts of all the religious groups in Algeria, there is a beam of unity under which all the sects resort to, that is Islam. This shows that a large proportion of Algerian cultures and social acts are inspired by different understandings of religion and the way each member of society practises it.

However, how can we label any religious practice as cultural? There is a need to discuss the notion of culture and its social significance in Algeria. First of all, culture is defined, according to Taylor (1958) (as cited in Moore 2004), as a complicated concept that includes knowledge, belief, law, morals, customs and other acquired practices in society. I would add to this definition of language, history, and religion although the word religion might be embedded in Taylor's definition as belief. In Algeria, there could be two

International Journal of Education and Knowledge Management (IJEKM) 
major sources that determine the guidelines of culture which are: religion and history. Almost all social and cultural practices are inspired by religion and history. A huge part of the culture in Algeria could be attributed to religion and this article is a clear manifestation of the religious power on society.

\section{Sunnis Influences on Society}

To start with, the Sunni group in Algeria has different social performance that may count as culturally appropriate. There are two types of this group: Salafists and Brotherhoods (as in Muslim Brotherhoods). Among the Salafist social (might also be labelled as cultural) practices are the way of dressing which is now sinking more into the Algerian society despite the efforts of some governmental authorities to prevent this in schools as claimed by Albilad tv (2017). Not all members of society dress Salafist likewise but there is no hostile behaviour towards this religious group and their appearance in such clothes. That is, there is a total acceptance of this as it represents a large part of Algerians and occupies a considerable place in society that none can deny. The dress code is described as a long white robe called 'Thobe' in Arabic or 'Khamis' in the Algerian dialect. This dress goes with 'under knees' (sometimes just above the ankle) trousers and growing facial hair as a beard.

The second social practice that is related to this group, in particular, is the huge number of books that this group promotes about religion (Jedide, 2012) and their understanding of Islam. I would not claim this as a social practice that is culturally recognised by all members of society but rather culturally recognised among the Salafists group that hold the same understanding of religion. It is also to emphasise that these religious sources promote specific understandings and practices of Islam that may not be found in other groups.

The third practice that is known to this group is that they are politically colourless (Jedide, 2012) and not in a total agreement with people who declare their political dimensions or belongings. The main role they have is to try to correct the religious practices concerned with innovations and to resort to the Islam of the companions and the Prophet (peace and blessing be upon him) (Jedide, 2012). This religious group has a strong religious speech and influence among many Algerian youths as they look at this group with high religious credibility.

The second Sunni group in Algeria is the Brotherhoods. This religious group is politically based and opposes the Salafist views on politics. This radical Islamic movement claims to redeem people from oppression, promote justice, and consider themselves the voice of all neglected societies in Algeria (Benali, 2018). This group believes in political struggle and has formed many political parties since the late 80s in Algeria. They are mostly known as 'Islamists' by most Algerians as they involve religion into politics and this common practice is recognised in society. This group expanded into universities where many students embraced the ideology of this group and their political work in Algeria since the 80s (Baher 2019) until nowadays.

The way these two Sunni groups interpret religion has affected their cultural practices with the presumption that each group holds: "it is our understanding that religion permits $\mathrm{x}$ or $\mathrm{y}$ activities (practices) within a specific $\mathrm{x}$ or $\mathrm{y}$ context and therefore there is a legitimate satisfying reason that allows the existence of $\mathrm{x}$ or $\mathrm{y}$ practices". The cultural practices I cited in this sub-section are extensions to thoughts and ideas, emerged from different religious interpretations, into society.

International Journal of Education and Knowledge Management (IJEKM) 
These two religious groups' (Salafists and Brotherhoods) practices are widely recognised as social and cultural practices especially among their followers. Algerians distinguish between both ideological extensions in society and their practices are more of cultural entities sinking into society's norms quickly. It is important to clarify that these practices do not fall into customs and traditions of the Algerian societies but very much into religion as this latest is an undeniable huge part of Algerian cultures along with other components of history, traditions, environment, and language as well. Sometimes traditions and religion overlap (see sub-section 7.2). Sometimes traditions (which are part of the cultural practices) can be justified through religious interpretations, but other times religion and traditions are repulsed. Likewise, traditions and customs are variable from one region to another in Algeria, the religious interpretations and practices fall in the same category. This is to emphasise that culture is in a dynamic change and what is culturally appropriate today might be less common and deniable in the future.

\section{Sufism's Social and Cultural Practices in Algeria}

This religious group is supported by religious authority in Algeria. It is very common especially between the elders' category of people. Three major cultural practices are held by this religious group and these are considered more of a traditional practice. These are Al-Wa'ada (also known as Zerda), the shrine, and Zawaya.

First of all, I start by discussing Al-Wa'ada and its influence on society. Bouwachma (2008) claims that this is one of the main practices of the Sufism sect in Algeria. This cultural practice is widely spread in many regions in Algeria (Kabyle regions and west of Algeria mainly) as it is held on a yearly basis (Rabi', 2018). The way this practice is held is through meetings of all regions that are nearby and they decide upon the date well in advance with many events that involve mainly banquets (Rabi', 2018). It is worth mentioning that not all people who celebrate Al-Wa'ada are Sufis rather some do not have an ideo-religious belonging but still, the origin and the adoption of this cultural practice are referenced back to Sufis.

Interesting things are carried out in this event for different reasons. Among the reasons that attract participants is the belief that if Zerda is not carried out, this will cause prosperity to cease (Makhehli, 2007). There are different practices of Al-Wa'ada in Algeria but the components are the same across all regions. Bouwachma (2008) asserts that the Shrine is strongly related to the spiritual practices of Al-Wa'ada.

The second Sufi's cultural practice is the shrine, which is a spiritual attachment to the event. The Shrine is usually the tomb of one of the righteous people and someone who was pious and believed to have descended from the Prophet (peace and blessing be upon him) dynasty and had some miracles (Bouwachma, 2008). One of the important rituals to be done when visiting a shrine is to give a sacrifice in a form of slaughtering an animal (chicken or sheep) in return for wishes to come true (Bouwachma, 2008).

Also, among the things that should be done is to light candles all over the shrine and henna the shrine (Al-Arabi, 2015). All these decorations are made because visitors believe that the spirit of the deceased person in the shrine is still free and can help visitors when called (Makhehli, 2007). These practices are part of the Algerian cultures that still enjoy some popularity in some regions. Furthermore, some of these cultural phenomena are held near Zawaya which contain a shrine.

The third cultural manifestation of Sufi's religious group is Zawaya. It is important to clarify that not all Zawaya are Sufi oriented places. Some are ideo-religious free. One of 
the roles of Zawaya is to teach the Quran. However, some other practices are related to politics. Although the political tendency of these religious institutions may not be culturally recognised, they are still politically acknowledged. The former president Abdel Aziz Bouteflika when elected in 1999 declared Zawaya independent from the authority of the Ministry of Religious Affairs, in return these institutions supported his policy (Boudhane, 2016). In a sense, Zawaya are considered supporters of authority in power as opposed to Muslim Brotherhoods in Algeria who claim to be in opposition currently. This ideological orientation of some Zawaya forces certain cultural practices on students who visit them regularly. These cultural practices are open to the public compared to Shia's which are still ambiguous in terms of their religious practices in Algeria.

The nature of these cited cultural practices are legislated by the Sufis sect in Algeria. It is people's attachment to their ideo-religious beliefs that dictate certain practices that later become purely culture-oriented practices. This to show and emphasise that there is a strong inextricable relationship between what people think of religion and how people practise it according to their interpretations. Moreover, some of the cultural practices use religion as a cover to advertise for their ideologies. It is, therefore, the religious power that is well-positioned in society and occupies a large space in Algerian societies.

\section{Shia and Ibadi Social Practices in Algeria}

In this sub-section, I present both Ibadi and Shia practices because they are minorities in Algeria and their practices may not be found in many regions. First of all, the Shia sect in Algeria has some religious practices that shape and govern their cultural life.

One of the main practices of Shia is Husseiniyet in Ashura. On that day, Hussein (the grandson of the prophet peace and blessing be upon him) was killed (Hazleton, 2009). The Shia celebrate this by beating their chest with mourning (Hazleton, 2009) and cutting wounds into their body with knives to show their sadness. It is one of the major practices in Shia sect followers but in Algeria, there is no public manifestation of this. This is why it may not occupy a space in Algerian cultures and social practices because Husseiniyet is a new religious belief among Algerians.

Interestingly, the same day of Ashura is also celebrated by Sunnis who fast the day (and the one before) and remember the day Allah saved Moses from Pharaoh, however, Shia followers celebrate the same day by grieving the death of Hussein. This is, maybe, a clear example of how different interpretations of religion take place in society and result in different social and cultural practices.

Ibadis may adhere to different cultural practices. There are three major cultural practices that I focus on to describe how religion influences social life and shapes most of the cultural schemas of Ibadis in Algeria. First of all, there is the Halaqa (the circle) which is a religious institution inspired by the understanding of Ibadis to religion, mostly. Halaqa joins a number of religious members of society who memorise the Quran and are wellknowledgeable in religious sciences (Bierschenk, 1988) that can help the society in religious matters. This is a simulation of a political position given to the Halaqa which is inspired by the role of religion in the Ibadi society. The characteristics that describe a member of a Halaqa allow him to be very socially sacred and grant his religious knowledge a supreme authority in the Mzabis society (Taghlet, 2014).

The second cultural practice is called 'Jama't al-'awamm' which is a tribal council to represent inhabitants of a town (Bierschenk, 1988). The role of this institution is restricted to solve disputes, make judgments on the criminal cases, and other council 
management (Bierschenk, 1988). Both institutions work together (Halaqa and Jama't al'awamm) to serve the Mzabis and solve the daily problems of groups and citizens (although the term 'citizens' may not be often quoted, 'group' is mostly used).

\section{Conclusion}

The voice of religion, as a result of this discussion, is strongly respected in Algeria. The social etiquettes, if not derived from religion or against the teaching of religion, may have little importance compared with the religious concepts.

This article presented the various religious understandings in Algeria and the reflections of such interpretations on Algerian societies and daily practices, claiming that religion is the main source of cultural legislation. In the light of the secularism movement that the world witnesses, Algeria is still a conservative country and strictly binding to the religious laws in social life. Globalisation effects may have influenced the way some Algerians consider religion in society nowadays and this is not a guided movement towards secularism. A foreigner walking to any Algerian city can still notice many forms that entail people's attachment to Islamic rites.

Having said all this, however, this is not to claim that Islam as a religion contradicts itself rather it shows that the practice of religion by some of its followers opens many doors to views and ideas in an attempt to interpret religion. That is, some of the religious interpretations are to support religious practices and not to enrich the understanding of sacred scripts. The example of Zerda can be manifested to address this issue. Although some of the ritual practices of Zerda are against the teaching of Islam, the followers of this sect defend their practices from a religious point of view instead. Understandably, some of the religious practices become cults that are very difficult to get rid of (if assumed that they run against the teaching of Islam). People practising such rituals may address this from their religious point of view to attract the sympathy of others who do not know much about certain rituals.

Future research on the role of religion in Algeria can touch on the involvement of Islam in politics in Algeria. This combination of religion and politics can reveal many interesting aspects that resulted from this integration.

\section{References}

Al-Arabi, R. (2015). الزردة والوعدات تقاليد بونة الخالدة. Wakt Eldjazair online. Available from: https://wakteldjazair.com/?p=15479. (Accessed 27 February 2019).

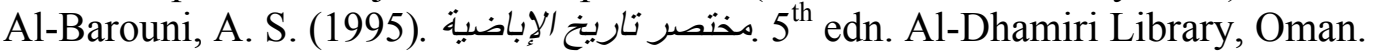

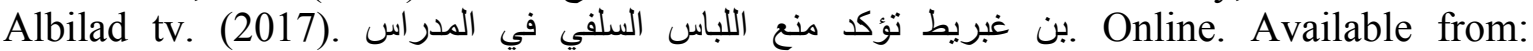
https://www.youtube.com/watch?v=xcS6zvIYOnM. (accessed 26 February 2019).

Al-Khattab, N. (trans.). (2008). English translation of Sunan Abu Dawud. Vol. 5. Darussalam, Riyadh: 155.

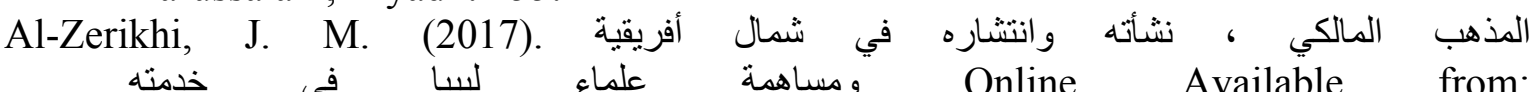

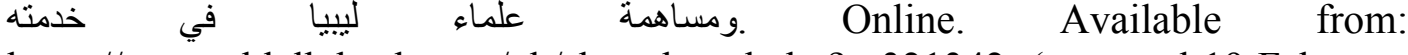
https://www.ahlalhdeeth.com/vb/showthread.php?t=321342. (accessed 19 February 2019).

Atbi, H. (2015). شيعة الجزائر.. أقلية تعيش بصمت وسط التجاهل الرسمي و الرفض الثعبي. Online article. Available from: https://arabic.cnn.com/world/2015/11/07/algeria-shiites. (Accessed 22 February 2019). 
Azazga, A. (2018). محمد عيسى: الجزائر صوفية و ليست إخوانية. Online. Available from: https://www.elwassat.com/frontpege/3713.html.(Accessed 13 February 2019).

Baher, A. (2019). الإخوان المسلمون في الجزائر .. ومحاولة العودة للمشهد السياسي. Online. Available from: http://www.islamist-movements.com/2711. (Accessed 27 February 2019).

Ben Massoud, A. (2018). أخرج معظم الجزائريين من "أهل السنة" .. "فركوس" شيخ السلفية في الجزائر. Online. Available from: https://www.sasapost.com/algerian-salafism-and-farkous/. (Accessed 20 February 2019).

Benaissa, M. (2010). المجتمع و التنمية في الجز ائر: أو لا: الثرائح الإجتماعية عند مشروع بناء الدولة الحديثة.

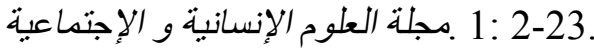

Benali, A. (2018). أصناف الممارسات السياسية في الجزائر. Online article. Available from:

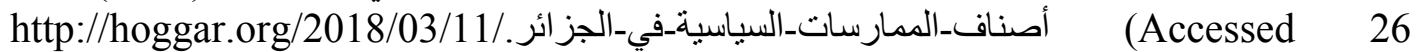
February 2019).

Ben-Khalifa, A. (2018). سبعة آلاف شيعي في الجزائر. Online. Available from: http://akhbarelyoum.dz/ar/index.php?option=com_content\&tmpl=component\&id=2 51269. (Accessed 22 February 2019).

Bergunder, M. (2014). What is religion? The unexplained subject matter of religious studies. Method and Theory in the Study of Religion 26: 246-286.

Beyers, J. (2017). Religion and culture: revising a close relative. HTS theologies studies/Theological studies 73, 1: 1-9. Available from: https://doi. org/10.4102/hts.v73i1.3864. (Accessed 11 February 2019).

Bierschenk, T. (1988). Religion and political structure: remarks on Ibadism in Oman and the Mzab (Algeria). Studia Islamica 68: 107-127.

Boudhane, Y. (2016). "الزو ايا بالجزائر.. من تعليم القرآن إلى منح "صكوك الغفران. Online. Available

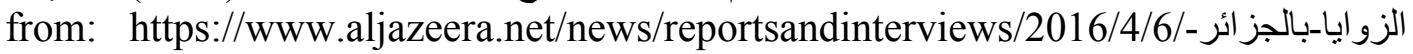

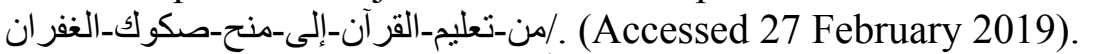

Boughdiri, K. (2015). الطرق الصوفية في الجزائر: الطريقة التيجانية نموذجا: دراسة أنثروبولوجية بمنطقية بسكرة. Ph.D. Thesis. Universite Setif 2, Setif.

Bouwachma, H. (2008). الو عدة التمثل و الممارسة، در اسة أنثروبولوجية بمنطقة أو لاد نهار. Insaniyat 39, 40: 83-101.

Boyle, K. and Sheen, J. (eds.) (1997). Freedom of religion and belief: a world report. Routledge, London.

Daoud, K. (2013). Djazairi : le manifeste de Ma Langue. Online. Available from: https://www.algerie-focus.com/2013/06/djazairi-le-manifeste-de-ma-langue-parkamel-daoud/. (Accessed 12 February 2019).

Daoudi, K. (2012). التعاون و الترجيح في المذهب الإباضي: دراسة مقارنة بالمذاهب الأخرى. PhD thesis. University of Oran.

Dawes, G. W. and Maclaurin, J. (2013). What is religion? Identifying the explanandum. In: Dawes, G. W. and Maclaurin, J. (eds.) a new science of religion. Routledge, London: 11-25.

Derwing, B. L. (1973). Transformational grammar as a theory of language acquisition: a study in the empirical, conceptual and methodological foundations of contemporary linguistics. Cambridge University Press, London.

Dhib, B. (2017). مختصون يتحدثون ل"المساء" حول المرجعية الدينية في الجزائر: المرجعية بأبعادها الوطنية . Online. Available from: https://www.elmassa.com/dz/index.php/component/k2/item/31284. (Accessed 20 February 2019).

Entelis, J. P. (2016). Algeria: the revolution institutionalised. $2^{\text {nd }}$ edn. Routledge, London. 
Furner, J. (2004). Conceptual analysis: a method for understanding information as evidence, and evidence as information. Archival Science 4: 233-265.

Grus, J. (2009). Your religion is false. Brightwalton, Washington Dc.

Hadji, F. (2018). Regionalism in Algeria: a balanced development option. العلوم مجلة 15, 26: 118-129.

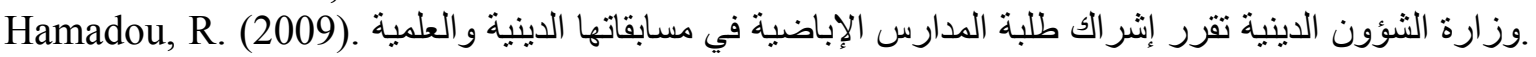
Online article. Available from: https://www.djazairess.com/alfadjr/110638. (Accessed 25 February 2019).

Harrison, V. (2006). The pragmatics of defining religion in a multi-cultural world. The International Journal for Philosophy of Religion 59: 133-152.

Hazleton, L. (2009). After the prophet: the epic story of the Shia-Sunni split in Islam. $1^{\text {st }}$ edn. Doubleday, New York.

Herbi, M. (2010). The cultural grounds for the Algerian nation. Insaniyat 47, 48: 11-19.

Jedide, F. Z. (2012). الظاهرة السلفية عند النساء في تلمسان: دراسة أنثروبولوجية. Magister thesis. University of Abu-Bakr Bel-Khayed, Tlemcen.

Johnston, M. P. (2014). Secondary data analysis: a method of which the time has come. Qualitative and Quantitative Methods in Libraries 3: 619-326.

Kettani, H. (2010). Muslim population in Africa: 1950- 2020. International Journal of Environmental Science and Development 1, 2: 136-142.

Khaladi, M. 2010. التعدد اللغوي في الجزائر) 1, 22:89-83.

Khan, M. M (trans.) (1997). The translation of the meanings of Sahih Al-Bukhari: ArabicEnglish. Vol. 9. Darussalam, Riyadh: 271.

Knysh, A. (2017). Sufism: a new history of Islamic mysticism. Princeton University Press, Oxford.

Koenig, H. G. and Al Shohaib, S. (2014). Health and well-being in Islamic societies; background, research, and applications. Springer, London.

Makhehli, M. (2007). قراءة أنثروبولوجية لظاهرة الو عدة من طقوس عقائدية إلى تعبير ات حضارية. Online

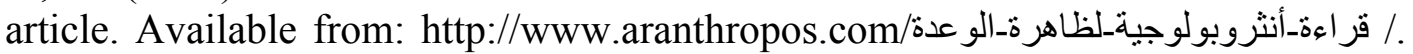
(Accessed 27 February 2019).

Mensour, M. (2010). القبلية و السلطة و المجتم في الجزائر: بحث أنثروبولوجي في المجال السياسي التيهرتي. $\mathrm{PhD}$ thesis. University of Oran.

Moore, J. D. (2004). Visions of culture: an introduction to anthropological theories and theorists. $2^{\text {nd }}$ edn. Altamira Press, Oxford.

Nye, M. 2008. Religion: the basics. $2^{\text {nd }}$ edn. Routledge, London: 2.

Rabi', H. (2018). الو عدة.. تقليد جزائري يعود بعد توقفه إبان عشرية الإرهاب. Meem magazine online.

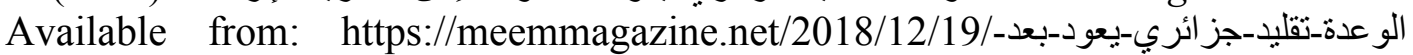
(Accessed 27 February 2019).

Rodriguez-Blanco, V. (2005). Method in law: revision and description. In: Coyle, S. and Pavlakos, G. (eds.) Jurisprudence or legal science? A debate about the nature of legal theory. Hart, Oxford: 63-88.

Saad Allah, A. (1998). تاريخ الجزائر الثقافي. Vol. 1-10. دار الغرب الإسلامي, Beirut.

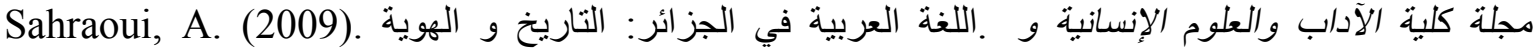
(5: 79-112.

Sawe, E. (2017). Religious beliefs in Algeria. Online. Available from: https://www.worldatlas.com/articles/religious-beliefs-in-algeria.html. [Accessed 13 February 2019]. 


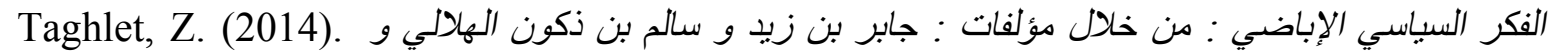
الدار التونسية للكتاب .البرادي و الثماخي (2016), Tunis.

Waqas, S. M. (2016). Shia religion: history, theology, and philosophy. Xavier University, Ohio.

Williams, R. (1998). The analysis of culture. In: Storey, J (ed.) cultural theory and popular culture: a reader. $2^{\text {nd }}$ edn. The University of Georgia Press, Georgia: 48-56. 